Etnográfica

Revista do Centro em Rede de Investigação em

Antropologia

vol. $24(2) \mid 2020$

Vol. $24(2)$

\title{
Expectations of tourism: hope, disappointment and tourism development in Vila Real (Douro, Portugal)
}

Expectativas de turismo: esperança, frustração e desenvolvimento turístico em Vila Real (Douro, Portugal)

\section{Lorenzo Bordonaro}

\section{(2) OpenEdition}

Journals

Electronic version

URL: https://journals.openedition.org/etnografica/7964

DOI: $10.4000 /$ etnografica.7964

ISSN: 2182-2891

\section{Publisher}

Centro em Rede de Investigação em Antropologia

\section{Printed version}

Date of publication: 1 June 2020

Number of pages: 289-314

ISSN: 0873-6561

\section{Electronic reference}

Lorenzo Bordonaro, "Expectations of tourism: hope, disappointment and tourism development in Vila Real (Douro, Portugal)", Etnográfica [Online], vol. 24 (2) | 2020, Online since 31 July 2020, connection on 19 January 2022. URL: http://journals.openedition.org/etnografica/7964 ; DOI: https://doi.org/ 10.4000/etnografica.7964

\section{(c) (i) (8)}

Etnográfica is licensed under a Creative Commons Attribution-NonCommercial 4.0 International License. 


\section{Expectations of tourism: hope, disappointment and tourism development in Vila Real (Douro, Portugal)}

\section{Lorenzo Bordonaro}

In this article, based on ethnographic research in Vila Real, Portugal, and carried out within the framework of the "Dourotur" research project, I describe local expectations of tourism in a context of prolonged economic decay and marginalization by national economic policies. Though acknowledging local demands for tourism as legitimate, I question the too straightforward link between tourism and local development that has become a mantra in Portugal. I maintain that, in order to be effective and face local expectations, tourism development policies need to be adapted to local territories and developed in a participative and sustainable form.

KEYWORDS: tourism, development, Portugal, Douro, Vila Real.

Expectativas de turismo: esperança, frustração e desenvolvimento turístico em Vila Real (Douro, Portugal) - Neste artigo, baseado em pesquisa etnográfica em Vila Real, Portugal, e desenvolvido no âmbito do projeto "Dourotur", descrevo as expectativas locais em relação ao turismo num contexto de prolongado declino económico e de marginalização por parte das políticas económicas nacionais. Embora reconheça como legítimas as demandas locais para um maior desenvolvimento turístico da região, questiono a ligação direta e automática entre turismo e desenvolvimento local que se tem tornado recorrente na retórica política e económica em Portugal. Defendo aqui que, para se tornarem realmente eficazes e responderem às demandas locais, as políticas de desenvolvimento turístico têm de ser adaptadas aos territórios locais e desenvolvidas de forma participativa e sustentável.

PALAVRAS-CHAVE: turismo, desenvolvimento, Portugal, Douro, Vila Real.

BORDONARO, Lorenzo (lorenzo.bordonaro@gmail.com) - Cetrad-UTAD, Portugal. 


\begin{abstract}
"In current efforts to make tourism participatory and to involve local residents as decision makers in tourism projects, anthropologists can make a significant contribution to the field by focusing more attention on the reasons local residents choose to, or are able to, become involved in tourism" (Stronza 2001: 276).
\end{abstract}

\title{
INTRODUCTION
}

"Forty-three-year old Rui Santos is one of the few tinsmiths left in Vila Real. Rui learnt his art from his father, who is now 80. Beside the tinware workshop is Rui's tiny two-room shop, located not far the city historic center. It displays several tourist souvenirs, clay pots and figures. Business is not going too well, he admits: "people prefer stuff made in plastic today, we work with specific orders, or repairing things, or with handicraft.' However, you really couldn't say that Rui lacks initiative or an entrepreneurial spirit. As a craftsman, he enjoys some success. He has won several local design prizes, and by pure chance, as we were chatting national TV coverage for the International Day of the Craftsman was aired on Portugal's national TV, including a short interview with Rui himself. Like many others in Vila Real, Rui is deeply dissatisfied with the lack of tourism. 'Look at Lisbon, look at Porto, he exclaimed angrily, that is a goldmine! I just can't understand why they don't develop tourism here in the Douro. I have been saying this for years. There are already tourists who pay to go work in the vineyards! I am telling you: tourists will pay to come here and sleep in the haystacks all over the countryside.' Rui has traveled as a tourist to several places in the world, and was especially impressed by Morocco, where, he claims, tourists go crazy for the local handicraft. 'Here, on the contrary, just a few tens of tourists enter in my shop every year. This is what we have here. We don't have museums, we don't have beaches: we have the Douro, the vineyards, the festivals in the villages. Our tradition is our richness. We need people passing and staying here, to revitalize Vila Real, to change things here, that's what is needed here" "[from my field notes, interview with Rui Santos, 14th May 2017].

Since tourism has become a leading academic subject in different disciplinary areas and is one of the largest world economic sectors, assessing the positive and negative effects of this activity has become an increasingly urgent but also controversial task, even in ethical terms (Caton 2012). Even though authors today tend to highlight the multiple and diverse effects (both positive and negative, at times contradictory) of tourism on destinations (Jafari 1990; Meethan 2001; Ateljevic, Pritchard and Morgan 2007; Singh 2012), concerns have been raised about the negative impacts this activity can have on local communities. In particular, research conducted in rural areas and in developing countries points to tourism's disruptive effects on local cultural 
narratives and social structures, and its influence on social stratification and economic dependency without significant improvement in quality of life or individual income (Stronza 2001: 268; see also infra). At the cultural level, some scholars (e.g. Urry and Larsen 2011) also allege that tourism menaces local "authenticity," transforming cultural traits into purely performed products for the gaze of the tourists. In this perspective, in several cases tourism has been assumed to be an imposition on local communities.

More recently though, a number of authors has deepened our understanding of local engagement with tourism, responding to Amanda Stronza's appeal for an effort to understand "why people and host communities engage in tourism in particular ways" without assuming that "tourism has been imposed on locals, not sought, and not invited" (Stronza 2001: 262). Noel Salazar, for example, has provided an interesting insight into how local destinations and global international tourism are intertwined, overlapping and clashing. His ethnographic approach to local tour guiding in particular, showed how tourism and local imaginaries are glocally shaped rather than merely imposed from top to bottom (Salazar 2010). Research by David Picard in La Réunion also offered a complex and nuanced portrait of these dynamics, highlighting local efforts and adaptation to international tourism demands and imaginaries (Picard 2011 ). Pérez and Inawinapi (2007) also showed how for the Kuna in Panama, tourism is a locally-initiated effort and a bottom-up process. This article (based on ethnographic research in Vila Real, Portugal, carried out in 2017 within the framework of the "Dourotur" research project) is meant to be a contribution to this literature. ${ }^{1}$ In it, I describe local expectations of tourism, reading them in a context of prolonged economic decay and marginalization by national economic policies. Though I acknowledge local demands for tourism as legitimate, I also question the too straightforward link between tourism and local development that has become a mantra in Portugal. I maintain that, in order to be effective and meet local expectations, tourism development policies need to be adapted to local territories and developed in a participative and sustainable form.

\section{THE DOURO REGION AND VILA REAL: BETWEEN DECAY, EMIGRATION AND THE WILL TO BE MODERN}

With a population of 51,009 (in 2013 - last available data), ${ }^{2}$ the town of Vila Real is the capital of the homonymous council and district located in

I Hosted by Cetrad research center at UTAD and coordinated by Xerardo Pereiro Pérez (Cetrad-UTAD), project "Dourotur - Tourism and technological innovation in the Douro" (NORTE-01-0145-FEDER-000014) was cofounded by the European Regional Development Fund through Norte 2020 (Programa Operacional Regional do Norte 2014/2020).

2 Data available at $<$ https://www.ine.pt/xportal/xmain?xpid=INE\&xpgid=ine_unid_territorial\&me nuBOUI $=13707095 \&$ contexto $=$ ut $\&$ selTab $=$ tab3 $>($ last access in December 2019) 
the Douro region in northeast Portugal. It is renowned worldwide as the location of the Alto Douro Wine Region, which was declared a UNESCO World Heritage site in 2001, as the port wine production zone, and for its dramatic vineyard landscapes. However, the Douro region ${ }^{3}$ has not been immune to the decline of rural areas that has marked Portugal (and Europe) since the second half of the $20^{\text {th }}$ century. These territories have been heavily affected by the transformation of the agricultural sector and by EU policies that, coupled with the weakness of the secondary and tertiary sectors, brought about a prolonged lack of new job opportunities and consequent emigration, land abandonment, and a growing aging population (Pina 2007). ${ }^{4}$ Even recent demographic data (2011) show a negative migratory balance in the region and an economy still linked to the primary/agricultural sector. It is in a deep crisis: the Portuguese North Region had the lowest national GDP per capita in 2011 , which followed the particularly negative performance of the Portuguese economy and the structural adjustment imposed by international institutions on the country in those years (CCDR-N 2013). Within the North Region, the Douro NUT III had the second lowest GDP per capita in the whole of Portugal between 1995 and 2011 (CCDR-N 2013: 14). While in the Porto urban area population and economy have been growing, demographic data show that the Douro had one of the worst national migratory balances (1995-2011), with more than $10 \%$ of bank deposits coming from migrants (against a national average of $3.2 \%$ ), one of the lowest purchasing power in the country (Oliveira 2014), and negative life quality indicators (Gomes and Dinis 2006). Despite the fact that several EU-funded projects targeted the region after Portugal joined the union in 1986 (including the AIBT Douro and the ProDouro, among others), negative economic and demographic trends seemed unstoppable (INE 2002; Cristóvão et al. 2003; Cristóvão 2005; INE 2012).

Amid these regional negative trends, Vila Real, as the district capital and the larger urban area in the Douro, has shown in the past few decades a slow growth in resident population (Cristóvão 2005: 10; Pina 2007: 303-304; INE 2012) that is evident in the rise of hundreds of apartment buildings, some modern public buildings, shopping malls and infrastructures.

Besides internal migration from other rural areas and the impact of the retornados (Portuguese citizens returning to their country from the former African colonies that Portugal lost in 1974), major transformations and population growth also impacted the city when the Polytechnic Institute of Vila Real was created in 1973. This institution was later transformed into

3 The research for this article was carried out between 2016 and 2017 in the Douro NUT III territory. NUTs are statistic territories created by the EU. The Douro NUT III territory includes 19 councils (see figure 1$)$.

4 See Pina (2007) for a comprehensive analysis of the region agricultural sector. 


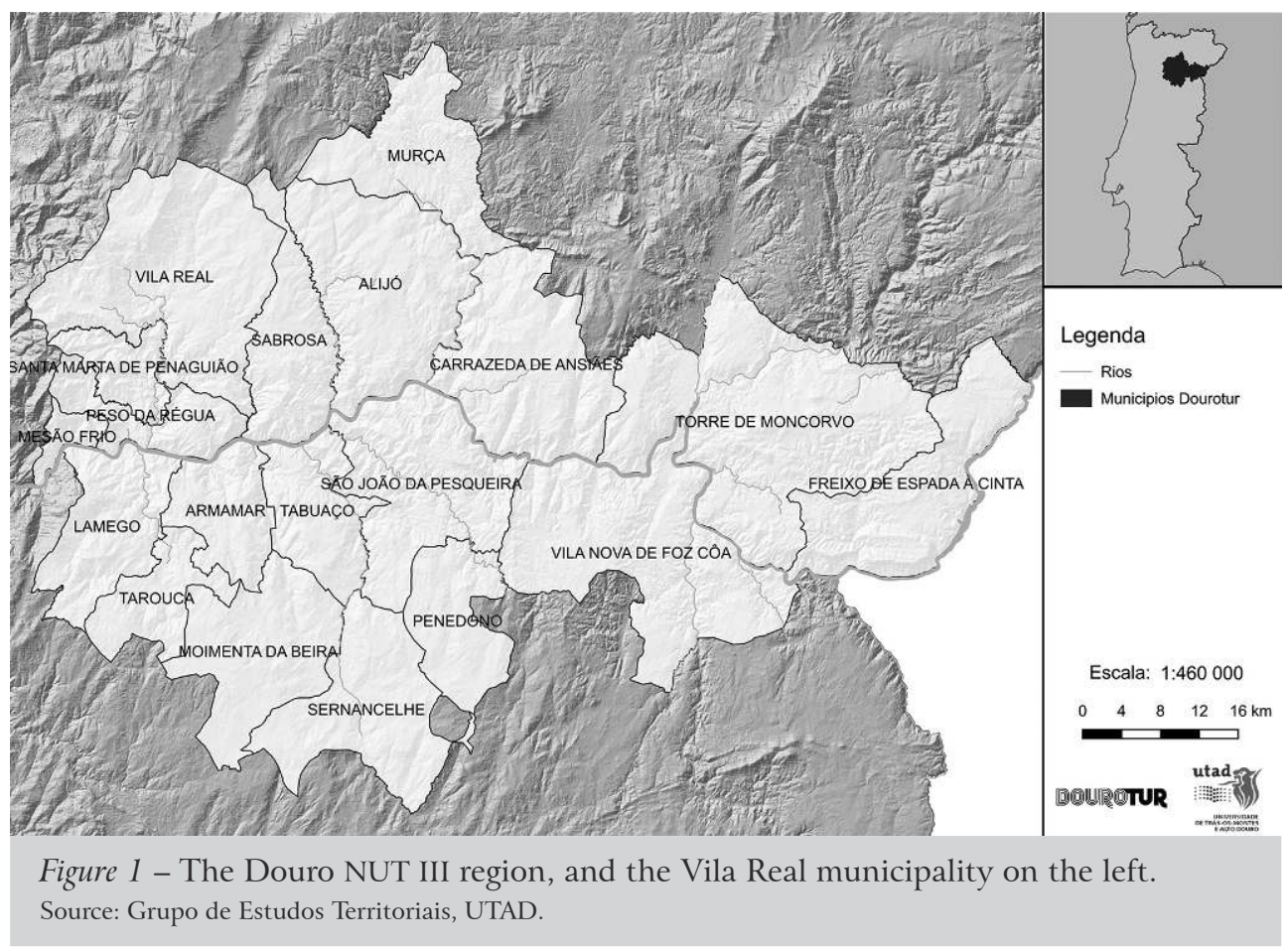

the Instituto Universitário Trás-os-Montes e Alto Douro (IUTAD) in 1979, and lately, in 1986, into the public university UTAD (Universidade de Trás-os-Montes e Alto Douro). The rise in number of students over the years (there were 8000 students enrolled in 2017), the administrative personnel and the professors, and all the temporary events organized by the institution (congress, seminars, etc.) have brought new life, money and population to this small town.

The demand for accommodation, however, created a massive real estate bubble that allowed for the investment of capital saved by migrants and sent back to Portugal. This sparked growth in the banking sector and dramatically transformed the city itself. The real estate and construction sector grew dramatically with this new demand from university students, professors and administrative personnel (besides the university campus itself), making the city grow in a rapid, disorderly and chaotic manner, with little or no urban planning (Botelho 2012). ${ }^{5}$ Apartment blocks with ten or more floors have

5 Analysis of the slight growth of resident population in Vila Real (which passed from 44,550 in 1970 to 51,850 in 2011) is not representative of the impact that the local university has had on the town and its urbanistic appearance. Only a part of the students officially residing in Vila Real, many commute weekly from their rural villages, attending lessons during the week and going back to their parents' homes during the weekend. 
been built together with service buildings such as hypermodern shopping malls, supermarkets, big food chains, private hospitals, and (only) one large scale hotel. Vila Real's historic center is today limited to a tiny area, with several abandoned buildings and shops.

If this gave the construction sector some fresh air (Pina 2007: 302), it also produced a university and service town that is poorly attractive in architectonical and touristic terms, and with no major productive sector (Cabral e Sousa 2001: 4-5; INE 2012). Despite the actual advantage for flat owners, the relative growth of residents, the further development of the university and the cultural events that are being regularly organized in the city, Vila Real's wealth is mostly apparent, is not diffused, and does not yet trigger any tangible economic growth or job creation. Emigration towards the cities on the coastline, Porto or Lisbon, or to other countries within the EU, is still a reality for many young people who cannot find satisfactory life opportunities in Vila Real or in the other municipalities of the Douro region. In fact, emigration in the wider Douro region has been, and still is, the principal motor of the local economy. The material symbols of this massive labor migration are the thousands pretentious new homes scattered through the valleys.

This continued lack of opportunities for young people was dramatically evident in a set of group discussions I carried out in 2017 with students from the BA in Tourism at UTAD university. These 18/19-year-olds accused the older residents of Vila Real (and, more generally, of Douro) of a lack of initiative, energy and openness. "There is nothing here," some of them told me, "people here are lacking initiative, creative energy, entrepreneurial spirit." Vila Real was described by these young enthusiastic students as "sleepy," a place where people need to "wake up a little bit" and seize the opportunities that are available today. On the same tone, Maurício, a real-estate agent who recently came back to Vila Real after 20 years in Luxembourg, told me that the city had actually "evolved" but that job opportunities were as scant as when he left several years earlier.

Research for this article was carried out ethnographically. In-depth interviews were necessarily had with a limited number of people, and are not per se meant to be statistically representative of the entire population of Vila Real. On an ethnographic sensibility tone though, and in more general terms, during my research in the city I sensed a widespread emotional nuance, a structure of feeling, a craving for economic development mixed with a certain anxiety of "missing it" (não conseguir), of "losing the chance" (perder a oportunidade). ${ }^{6}$ Again.

6 The concept of "structure of feeling" is borrowed from Raymond Williams through Philip Thomas, referring to "a specifically interrelated - hence structured - set of elements (including semantic categories, feelings, practices, and relations) that are both a product of and a means of formulating understanding of lived experiences and that, though they escape formal definition, exert a palpable hold on social consciousness" (Thomas 2002: 369). 
The prolonged economic decline of the entire region, coupled with stillwidespread national representations of the Douro as the rural and "traditional" region, probably lie behind these feelings. As a matter of fact, the Estado Novo regime, which dominated the country from 1933 to the carnation revolution in 1974, supported and incentivized a folkloric and ideological representation of the interior North of Portugal as a symbol of Portuguese authenticity, a hard land where the Portuguese spirit revealed itself through heroic agricultural labor. Younger people especially are still trying to get rid of this picture, wrapping their legitimate aspirations for a job and a future in the region with a rhetoric of modernization, entrepreneurialism and progress.

The new shopping mall (Nosso Shopping - "Our Shopping"), dominates the city landscape at night with its hypermodern-architecture blue spaceship-like lights. Both the mall and the new cable highway bridge (whose visual impact on the landscape is dramatic) are landmarks of modernity that are proudly praised by people in Vila Real. The 2017 motto for the city's world famous urban car racing circuit was Acelera Vila Real ("Accelerate Vila Real"), and the aspiration to grow was also suggested by the campaign slogans of the town's main political parties competing in the 2017 local elections, respectively "Advance +" (Avançar + ) by the Socialist Party, and "Vila Real with ambition," (Vila Real com Ambição) by the center-right Social-Democratic Party.

It is within this "enchantment for modernity," 7 aspirations for development and the search for opportunities (which the present day neoliberal national ideology is doing its best to cultivate) that tourism has come to be locally understood as a new hope, a new direct train toward modernization and prosperity, a train that is passing nearby (certainly through Porto and Lisbon), but that the Douro risks missing. ${ }^{8}$

Geographer David Harvey pointed out in 1989 that the major shift in urban economies in the previous decades had been from managerialism to

7 A discussion on "modernity" will necessarily bring us quite afar from the purpose of this article. Though in another context, I devoted a thorough analysis to the notion of modernity in previous publications (Bordonaro 2009). As an analytical tool of social sciences for understanding change, "modernity" has received countless criticism in the recent decades. A key-word of the grand narratives of social evolution of Western social and political science, this concept proved to be too ideologically biased and theoretically inapt to describe social change. Discarding modernity as an appropriate analytical tool for understanding social and cultural change however, does not mean overlooking the powerful hold that this idea has in many popular fields of discourse. The literature on the subject is vast: see, among others, Arce and Long (2000), Gaonkar (2001), Eisenstadt (2001), Lichtblau (1999), Rofel (1999). It is in this perspective that the term is used in the following pages.

8 Cui and Ryan argued that, within the Chinese rural context in which they carried out their research, tourism may be well received not simply for the immediate anticipated economic benefits but also as a proxy for modernization whereby rural communities that were previously marginalized are now perceived as part of a wider entity of national and possible international relationships. In other words, tourism represents the modern in opening access to a wider world (Cui and Ryan 2011 : 606, 611). 
entrepreneurialism (Harvey 1989). This approach to urban and public space in general has become mainstream in contemporary urban governance (see for ex. Hall and Hubbard 1998; Brenner and Theodore 2002). Accordingly, while several efforts have been made at the national level to increase the accessibility

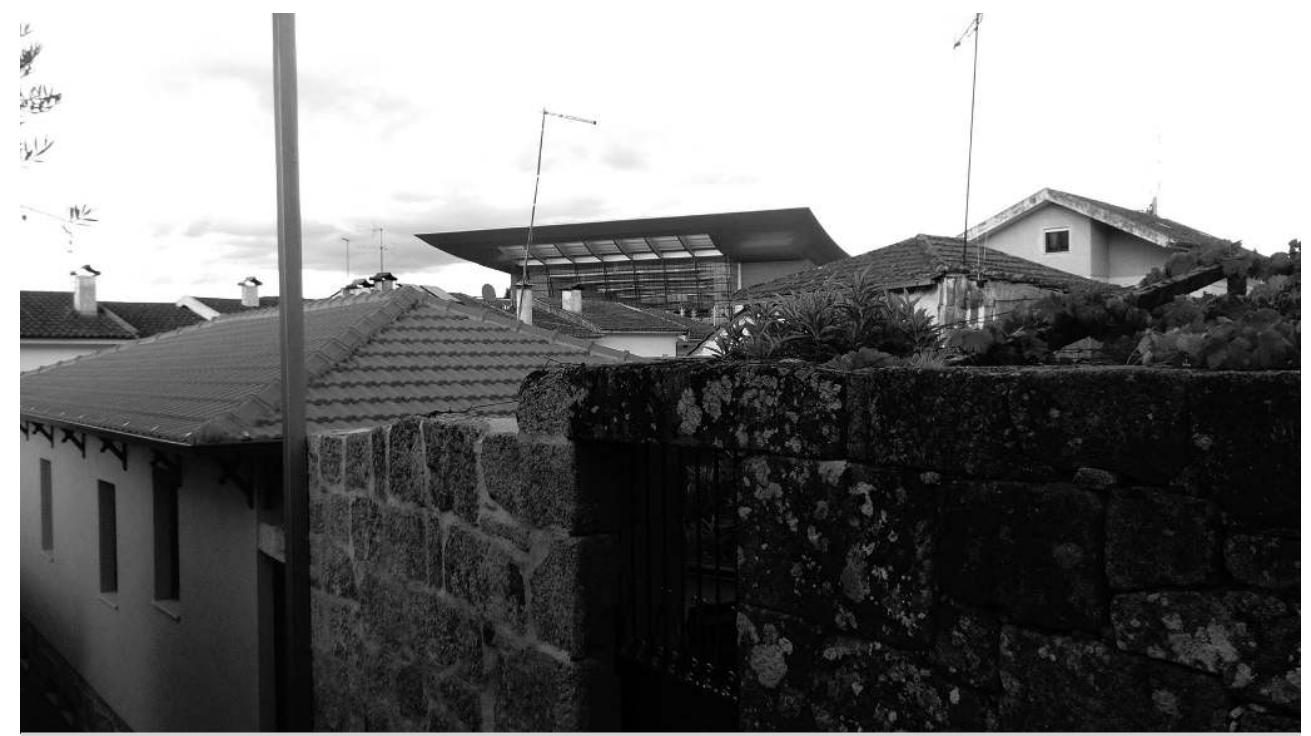

Figure 2 - The Nosso Shopping mall in the background. Photo: Lorenzo Bordonaro.

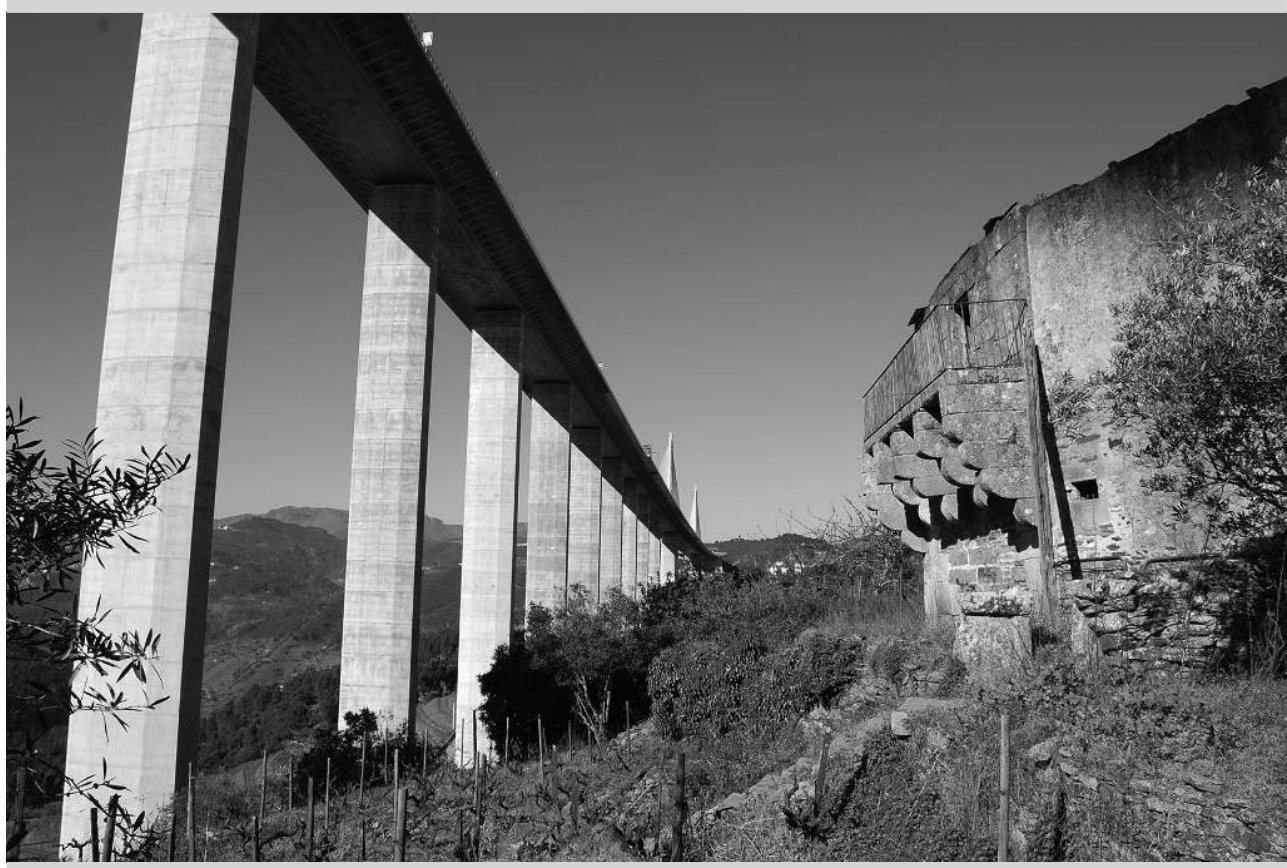

Figure 3 - The A24 highway bridge. Photo: Lorenzo Bordonaro. 
of the region (such as the A24 highway linking Viseu to Chaves and Galiza via Vila Real in 2007, or the Marão tunnel allowing a fastest connection with the city of Porto in 2016 via the A4 highway), ${ }^{9}$ local municipalities and regional governments in the Douro have been active in promoting the territory and stimulating local entrepreneurs, creating conditions for the rise of local startups taking advantage of the new glittering opportunity: tourism.

\section{EXPECTATIONS OF TOURISM}

The boom of tourism in Portugal in recent years has increased the aspirations of people in every region of the country to take advantage of this sector, in order to change a history that is often marked, as in the case of Douro, by decades of economic decline, depopulation and lack of opportunities (Ribeiro 2000). The increase of tourism in the Algarve region, and more recently in the two main cities of the country, Lisbon and Porto, has contributed to the spread of a vision of tourism as a "goose that lays golden eggs" in a country marked by negative economic turnout in all other sectors and severe debt and public expenditure cuts imposed by the EU and FMI until 2016. Strategic economic plans for the next decade issued by state agencies underline the potential of tourism and underpin local development policies based on investment in the tourist sector (Turismo de Portugal 2016).

Accordingly, my research in Vila Real shows a shared and widespread expectation that tourism could (and should) finally be the pathway to the long-awaited local development of the city and of the region, probably the only foreseeable one (Ribeiro 2000: 35-36). Residents' expectations were, however, coupled with pessimism, disappointment and some bitterness.

When part of the Douro valley was awarded the UNESCO Heritage Site label in 2001, everybody expected a rapid rise in the number of visitors and a new deal for the local economy. What happened instead was mostly a rise in the number of river cruises along the Douro river to the benefit of big nonlocal investors. These cruise ships, which departed from Porto and were often endowed with accommodation and a restaurant service, allowed but a limited circulation of tourists in the wider Douro territory, reducing local economic impact. In the last decade Vila Real, like many other smaller towns far from the river, has witnessed a very limited influence of tourism on its economy (Sousa 2013).

Mr. Jaime owns one of the main bars in Vila Real, with a small terrace on the central square of the city. He tells me he cannot complain about tourism, even though it is still a limited activity for him, comprising something like $10 \%$ of his annual income: 
"Tourism in Vila Real, and in the Douro, is still a recent thing. Ten years ago, there wasn't anything, but it has been growing little by little. Here in Vila Real though, it is basically during the three or four summer months. They arrive here by bus, from Régua, and they stay just 30, 60 minutes before going back. But as they stop right here, in front of my bar, I have my benefits. They come from Régua, and they all come from the river cruises, from Porto. They just stop a while and move over. They don't really have time to walk around. After all, they wouldn't have anywhere to sleep here in Vila Real, we just have one decent hotel, the Mira Corgo, and it's always full." 10

Rui Santos, the tinsmith we met at the beginning of the article, was particularly annoyed by the Porto-based Douro Azul, one of the main river cruise companies: "Douro Azul brings tourists from Porto, then brings them by bus from Régua to Mateus. They stop a few minutes in Vila Real, and off they go. I didn't see any increase in tourism in Vila Real recently." 11

As is well known, the great majority of international tourists reach the Douro region by river, traveling on large cruise ships leaving from Porto. These cruises, which can last from one to several days, are often included in larger travel programs marketed by tour operators worldwide. The river cruises programs commonly include short one-day visits by bus from the ports of Régua and Pinhão (on the Douro river) to a limited set of destinations, including the Casa de Mateus, Panoias, and a few selected quintas where tourists can have lunch and taste wines. ${ }^{12}$

Nuno has been working at the ticket office of Casa de Mateus for the past ten years. He confirmed to me that most tourists arrive by bus, in organized guided tours, from Régua. The number of visitors is impressive, especially during the high season: "During summer, we receive between 500 and 600 visitors per day. Most of them arrive by tourist bus. The majority are from the UK, Nordic countries and Germany. And we have a lot of senior tourism."

Marta, a 33-year-old woman who has been working at the ticket office of the Museu da Vila Velha (Old Town Museum) in Vila Real since its opening in 2008, claimed that the number of tourists is slowly increasing in the city, even though in most cases they spend just a few hours in town. Most visitors, she claimed, spend one day here and move on to other hamlets and attractions

10 Régua (or Peso da Régua) is the main river port in the upper Douro region, and is the main destination for the river cruises.

11 The Mateus palace (a few kilometers from the center of Vila Real) is a gorgeous XVIII century countryside palace and one of the main tourist destinations in the Vila Real council territory.

12 Panoias is a Roman archaeological site, located close to Vila Real. Quintas (farms) are wineries.

Some of the ancient ones host visitors, usually for lunch or wine tasting. 


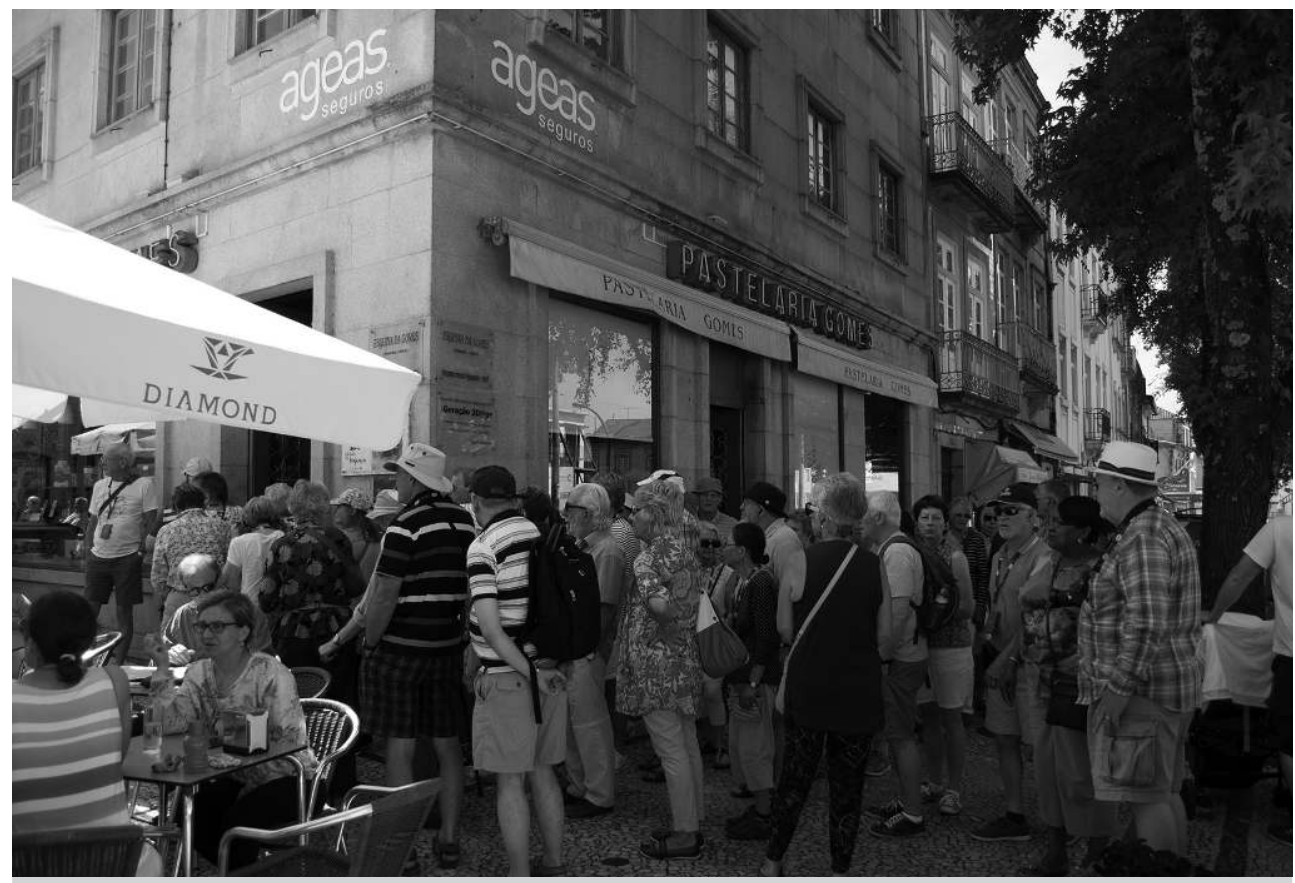

Figure 4 - A group of tourists queue up in from of Pastelaria Gomes, Vila Real (June 2017). Photo: Lorenzo Bordonaro.

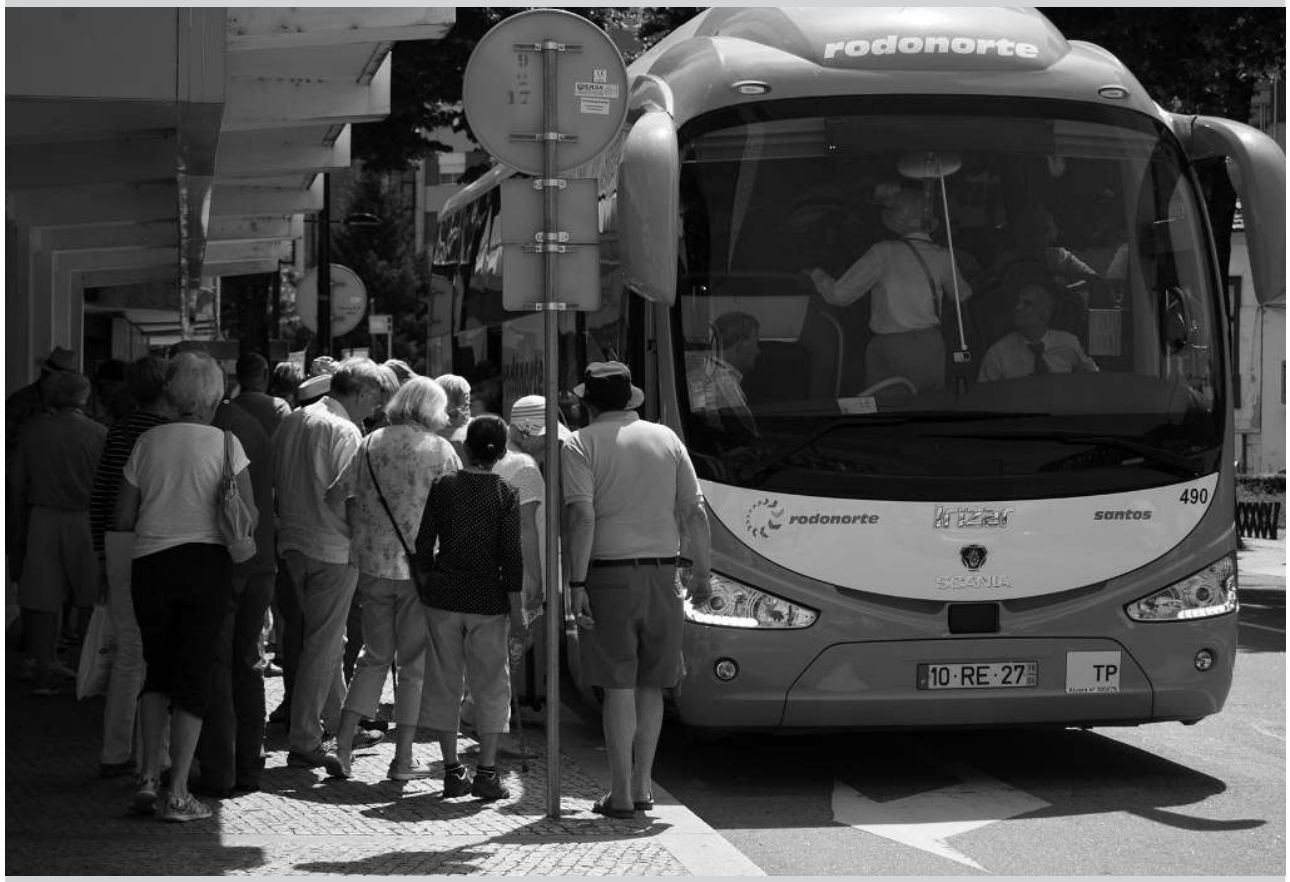

Figure 5 - A group of tourists embarking on a bus to leave after a short visit in Vila Real (June 2017). Photo: Lorenzo Bordonaro. 
in the region: "larger groups of tourists arrive as part of all-inclusive tours organized by the river cruise companies. They arrive from Porto up to Régua by ship, and are brought in guided tours to the Mateus palace. They also stop here in the city center of Vila Real, but it's a very short stay."

Tourism, according to Marta, would be very beneficial for the city. Tourism, she tells me with emphasis, "makes a city more active, and it's excellent for commerce. But if we want to be visited [sic] we have to open doors... Now with the opening of the Marão tunnel, it is much easier to get here. But we have to open our doors, show that we are not just a people enclosed between mountains."

Even though she acknowledges that the increase in tourism might bring about a rise in crime ("we never know who will come to visit us, and when you open the doors..."), she is definitely convinced that "tourism is good, under any respect" but that the current level of tourism in Vila Real is not sufficient. "Not at all, really," she told me, sadly shaking her head. "We need much more promotion. It's being done, but it should be much, much more. Especially in the cultural tourism area."

The issues of the unexplored potentiality and the allegedly scarce local institutional efforts for promoting the city and the region was also evident in the words of Manuel Tavares, the dynamic, intelligent and energetic assistant manager of the biggest hotel in Vila Real, the Mira Corgo. The Mira Corgo Hotel (4 stars, 166 rooms, 332 beds) is a 12 -storey building constructed on the rocky side of the Corgo river, in the city center. The traveled and experienced man, born in Chaves, had been working for 34 years in the hotel. Despite the improvements in accessibility, Manuel told me, there are political issues that contribute to the marginalization of the Douro and Trás-os-Montes regions. ${ }^{13}$ According to Manuel, if tourism has not grown in Vila Real as much as expected, it is also the politicians' fault:

"Portugal is a very centralized country, politics happens in Lisbon. We are not an autonomous region (like Galicia in Spain, for example): we should be more autonomous. You see, everybody that comes here is astonished: by the landscape, the gastronomy, the openness of the people, the air quality, the safety. The potentialities of Vila Real are not explored: why has the world-famous Vila Real car racing been downsized? Why has it been suspended for several years? There were English people who came here because Vila Real was renowned for its city car race. People were camping in the main avenue! Why don't they build a nature trail in the valley of the Corgo river? Vila Real could easily turn into the starting point for several tourist routes, to Chaves, Bragança, Montalegre..." 
Despite his complaining, he tells me that the Mira Corgo Hotel receives a large amount of commercial tourism throughout the year (conferences, business, etc.), and in summer especially many tourists come from across northern Europe who are interested in nature and spend a couple of days trekking in the Alvão national park. Manuel's faith in tourism is unshakeable: "When we have tourism we have advantages. Where would the Algarve be without tourism? We have now a direct flight from Newark to Faro! Can you imagine that? Tourism does not have any negative effect. Among trades, it is the most profitable: all we need is a work force, and for sure we have it. We just need the sun, and that's all. We have all the rest that is needed."

The potential benefits of tourism for the region are not being explored in the right way, claimed Manuel:

"Portugal is an open door for tourism, even though I think that this wave of tourism is not being availed of correctly. Tourism is bringing us advantages, but they are not being availed of. Take the Douro. Most tourists arrive here by river. And it is only in this area, the river cruises, that tourism is bringing about economic benefits. The Douro region is being explored by people who are outside the Douro itself. All the benefits go outside. Here in the region, we don't really see any advantage! Here in the Douro it has always been like this, since the time of the King's Company (Real Companhia). The Douro produces, and the results go outside. The Douro works, but the gain goes outside the region. What we are left with here is just seasonal underpaid jobs!"14

With tourists actually passing through the territory of Vila Real, but not staying and spending little on local commerce, restaurants or accommodation, the resentment of the people in Vila Real does not come as a surprise. A noteworthy flow of money and people is daily passing through the city, but only marginally benefiting the local economy.

I obviously did not get in touch with every person in Vila Real. Neither did I interview a statistically representative sample of people. Ethnography claims its epistemological validity from the researcher's presence on the field and from a wide variety of research strategies, well beyond the limited dispositive of the interview. I am also aware, in a hermeneutical perspective, that my inquiring about tourism and its actual benefit for the region activated or re-activated specific self-perceptions of Vila Real people.

Beyond this caveat however, if I was to synthesize the general feeling of the Vila Real people about tourism, it would be that their territory is being 
explored without them receiving noticeable advantage or profit: in general, they feel something is being stolen from them by the tour operators, over whom they have no control at all. Like Manuel, many of my interlocutors in Vila Real made a direct analogy with port wine, a regional Douro produce and a flagship of Portuguese exports: "Just as the wine we produce here in the Douro region is worldwide known as the port wine, the beauty of our landscape is exploited by the river cruise companies based in Porto," I was often told. The ghostly presence of tourism in Vila Real was interpreted as the last chapter in a history of poverty, exploration and national marginalization that has marked the region for decades.

\section{WHICH TOURISM, WHOSE DEVELOPMENT?}

\footnotetext{
"Too often, local leaders, with the assistance of state tourism agencies, march forward with strategies to attract visitors to rural regions with little concern and/ or effort placed on the impacts these visitors will create" (Marcouiller 1997: 339).
}

After the crisis years, when Portugal was lingering at the edge of bankruptcy with its finances controlled by the so-called troika, recent economic strategic planning highlighted the importance of tourism for the country. From the Ministry of Economy down to the councilmen in rural areas, tourism has come to be envisaged as the solution for the future of Portugal. According to the 2027 Strategic Plan for Tourism issued by the Portuguese Tourism Agency (Turismo de Portugal 2016), tourism is a key economic sector for Portugal and its main export economic activity. The average growth rate of tourist revenue has been $6.3 \%$ over the last ten years, and represented $6.3 \%$ of national PIB in 2015 (Turismo de Portugal 2016), even though this positive performance is paradoxically coupled by a slow decrease in the number of workers in the tourism sector ( $-0.4 \%$ annually), and a significant lower income for this sector's professionals (37\% less than the national average). Tourism in Portugal is also marked by dramatic regional asymmetries, with $90.3 \%$ of overnight stays spent by tourists in Portugal concentrated in the coastal area, leaving the interior territories somehow marginalized in this rapid growth process. The strategic documents therefore stress the importance and potentialities of tourism as a factor of regional development (Turismo de Portugal 2016; CCDR-N $2008 \mathrm{~b}$ ), and the Portuguese Tourism Agency has been implementing a specific funding line (under the program "Valorizar") for the touristic valorization of the interior regions. ${ }^{15}$ 
This vision is reflected in the approach of local governing entities (Ribeiro 2000; Bordonaro, Makanse and Mota 2017). According to José Maria Magalhães, councilman for Tourism in Vila Real, for example, the municipality lately made several efforts to elaborate a general strategy for the touristic development of the city, consulting the various stakeholders in the region and acknowledging that there is still much to do to develop the touristic sector in Vila Real. The councilman claimed that they have been striving to promote the city, participating in the most important international tourist fairs, and are aware that "we don't have big industries, we are a service city, we know that tourism is a strategic axis for economic development."

With such an appealing message of hope and unwavering faith in the straightforward link between tourism and local development, the disappointment of the residents in Vila Real was not surprising given that no significant improvement could be recorded despite the physical presence of thousands of tourists in the region. Previous field research carried out in the Douro as early as 2002 by Ribeiro and Marques had already contested the taken for granted link between tourism and the economic development of less favored regions. They came to the conclusion that "as far as the Portuguese case is concerned, the gap between the pro-touristic rhetoric and everyday practice is still considerable" (Ribeiro and Marques 2002: 212).

As a matter of fact, despite general optimism regarding the positive effects of tourism in the region, data collected by Ribeiro (2000) showed that the growth of tourism in the Douro region (though below expectations) had not brought about a corresponding increase in per capita PIB or a decrease in unemployment, nor had it lessened the desertification of the region, as had been expected (Ribeiro and Marques 2002).

More recently, Kastenholtz et al., in a final report assessing the effects of tourism on Portugal's rural regions, confirm earlier findings by Silva (2006), suggesting that

"Tourism can have a very significant role in the economic development of rural regions, due to its actual impacts and potential multiplier effects. Tourism though can have negative economic effects, especially when activities are not developed in a participatory way integrating the perspectives and interests of the various stakeholders. In several cases, the real potential of tourism to trigger a renewed local development have been questioned, especially due to massive investments resulting in weak positive economic impacts. Actually, especially in several remote rural areas, the link between tourism and development showed several flaws, mainly because the economic impacts were limited to just some sectors or social groups, without creating locally job opportunities or improving the life quality of local communities" (Kastenholz et al. 2014: 92-93). 
Frustrated by this tantalizing flow of tourists, people in Vila Real were rapidly shifting from "tourism-hungry" (Smith and Krannich 1998) to "tourism-angry."

Even though tourism is widely regarded as a means of achieving development in destination areas, and "the justification for its promotion in any area or region within the industrialized or less developed world, is its alleged contribution to development" (Sharpley 2015: 5), research on the impact of tourism on rural and economically weaker areas suggests that the link between tourism and local development should not be taken for granted. Studies show that tourism does not necessarily trigger local development or increase residents' quality of life. On the contrary, it can produce adverse economic, social, cultural and environmental effects (Young 1973; Turner and Ash 1975; Britton 1982; Wu 1982; Jurdao Arrones 1992; Brohman 1996; Amit and Dyck 2011; Urry and Larsen 2011). As Urry and Larsen claim, "the effects of tourism are complex and contradictory. There has been much discussion about the desirability of tourism as a strategy for economic development in so-called developing societies. This raises various difficult issues" (Urry and Larsen 2011: 73). As far back as 1982, Britton stressed the importance of "placing the study of tourism firmly within the dialogue on development" (Britton 1982: 332). Writing about "third world" countries' economies, he claimed that the promotion of tourism was a "highly ambiguous development strategy" (Britton 1982: 332). Jurdao also referred to tourism development as the "myth of tourism" and the "ideology of tourism" (Jurdao Arrones 1992). The link between tourism and development (for an interesting analysis, see Sharpley 2015), assumes that more tourism necessarily results in economic growth and the general improvement of the residents' quality of life through a trickle-down process - what Bernardo (2015: 4) compellingly defined as "the pro-tourism messianic movement." If we are not to repel this link a priori, then we should at least verify it case by case through in-depth research. As Mathieson and Wall underline, "(t)here is no inevitability in the tourist development process as it can stop, change direction, modify its character, and produce outcomes which are unexpected and difficult to predict" (Mathieson and Wall 1982: 13).

Recent statistical analyses show that tourists in the Douro region are not few, even though their distribution across the territory is far from homogeneous. The number of river cruise passengers in the Douro raised from 615,361 in 2014 , to 721,242 in 2015 , to 946,728 in 2016 while there were 212,495 hosts for a total of 337,664 overnight stays in 2015 (Bernardo 2017). ${ }^{16}$ By contrast, NUT III Douro's resident population was 205,157 in 2011 (INE 2012). As a

16 Passengers data available at < http://douro.apdl.pt/f? $\mathrm{p}=$ 100:6:10109235 149558:::6:P6_PAGINA: VIA_NAV_EST $>$ (last access in December 2019). 
matter of fact, the locals I interviewed did not generally complain about the lack of tourists, but rather of the kind and pattern of tourism that prevails in the region today. Apparently, tourism in the Douro has two features that leave residents deeply frustrated. In the first place, tourists concentrate in specific spots in the region, leaving other areas only marginally involved; secondly, tourists habitually arrive with all-inclusive tours on cruise ships, spending too little in the territory (as already pointed out by Ribeiro 1998) and primarily benefits firms that are not based in the region. The issue raised by those I interviewed was not simply that the number of tourists should be increased, but rather that the tourists who visit the Douro region should be made "locally profitable." I will always remember the words of the owner of a restaurant in Régua, one of the main destinations of the river cruises coming from Porto: "Tourists come here, of course they do, by the thousands! The problem is that they don't leave anything here, except their trash!"

From the point of view of most of my interlocutors, the problem with tourism in the Douro region is not so much its scarcity, but rather the adverse effects tourism commonly has on rural and economically depressed areas when its development occurs in a neoliberal economic context and when it is not properly managed. As has been pointed out, in these situations tourism creates social and economic gaps, concentrates in specific areas, and attracts mainly external investors and tour operators who have sufficient capital and expertise to take advantage of new tourism opportunities (Brohman 1996). Local residents are mostly employed in dependent, unskilled and underpaid jobs, but face accusations of lack of initiative or entrepreneurial mentality.

The words of my interlocutors must therefore be interpreted as a dramatic appeal for a shift in the model for tourism development that is being implemented, rather than as unconditional support for the increase of tourism in the region. People in Vila Real voiced a strong, if implicit, criticism of the kind of tourism that has been developing in the Douro, rightly demanding a kind of tourism development that could really be of advantage for the town and the region.

\section{AN ALTERNATIVE TOURISM FOR THE DOURO}

\footnotetext{
"Tourism is in fact a powerful social force that can achieve many important ends when its capacities are unfettered from the market fundamentalism of neoliberalism and instead are harnessed to meet human development imperatives and the wider public good" (Higgins-Desbiolles 2006: 1192).
}

My critical analysis of the tourism/development equation is not intended to ignore or dismiss local demands for change, transformation, and economic improvement. Quite the contrary. The point is not to demonize tourism, but 
rather to adapt it to local context, eschewing purely market-centered strategies and achieving a balance between economic advantage, environmental sustainability and an actual and diffused enhancement of the life quality of residents (Middleton and Hawkins 1998; Brohman 1996). As Richard Butler told me when discussing these issues, "growth per se is not negative, it depends on how you manage it." ${ }^{\prime 7}$ Despite legitimate critical stances, if tourism was adapted to the specific context and made sustainable in order to prevent the havoc that can arise from mass tourism, it could be an important means of sustaining a rural world otherwise doomed to abandonment and depopulation given the present economic statistics of Portugal and Europe.

However, the question of what kind of tourism can develop and effectively improve local communities, maintaining the right balance with cultural and environmental concerns, is a conundrum that still has to be sorted out. Referring to the specific situation of Portuguese rural regions, Kastenholz et al. claim with some pessimism that

"Developing tourism in rural areas according to the principle of sustainable development is an unchallengeable necessity to grant the survival of these spaces. However, despite this issue having been the object of several scientific studies, being included in several political discourses and integrating several entrepreneurial strategies, there are still many doubts about what kind of tourism development should be adopted in rural areas, in order for the principles of sustainable development to be correctly implemented" (Kastenholz et al. 2014: 51).

Trying to respond to this challenge, there has been in the last decades an increase in research on so-called "sustainable tourism" (Clarke 1997; Butler 1999; Sharpley 2000; Liu 2003; Bramwell 2011; Bramwell and Lane 2011; Weaver 2011), on alternative tourism (Eadington and Smith 1992; HigginsDesbiolles 2006, 2008), and, more recently, on responsible tourism following the 2002 Cape Town declaration (Goodwin 2007, 2016, 2017; Spenceley 2008; Leslie 2012; Camilleri 2016) ${ }^{18}$ Considering the tourism industry's size and its impacts on the environment, some authors claim that the expression “sustainable tourism” is actually oxymoronic (D'Eramo 2017: 11). However, the urgency for a change in tourism development strategies has seeped into global agencies' agendas. As is well known, 2017 was pronounced by UNWTO "International Year of Sustainable Tourism for Development." This concept recurrently pops up in Portuguese national and regional strategy documents,

17 Richard Butler, personal communication, 16 February, 2017.

18 For the Cape Town declaration, see < http://responsibletourismpartnership.org/cape-town-declarat ion-on-responsible-tourism/ > (last access in December 2019). 
often coupled with the expression "local development" (Turismo de Portugal 2016; TPNP 2015, 2017). Some recent planning in the region shows evidence of sensibility for environmental sustainability, proposing holistic tourism development strategies for the region (CCDR-N 2008a, 2008b) that are linked to the UNESCO Heritage preservation (CCDR-N 2014).

Despite the official statements, however, recent research by the "Dourotur" project (Bordonaro, Makanse and Mota 2017) with representative councilmen and councilwomen involved in tourism planning within the local councils in the Douro region demonstrated an effort to increase tourism and attract more visitors to maximize economic profits. However, there appeared to be little concern about managing tourism, and little or no adequate territorial planning. Climate change and environmental preservation should be key issues planning the future of tourism in the Douro region, but they were largely ignored, and local councils are almost completely devoid of efficient environmental monitoring instruments (Bordonaro, Makanse and Mota 2017). Back in 2000, Ribeiro was already pointing to the lack of environmental consciousness and the importance of assessing and minimizing the impact of touristic activities on the fragile natural ecosystem of the Douro region (Ribeiro 2000: 40-41). In 2017 , the situation seems largely unchanged.

As a matter of fact, the notion of sustainable tourism risks becoming a mere legitimizing discourse for an actually uncontrolled and unplanned tourism industry expansion unless there is a concrete and effective translation into tourism management by both national and local ruling bodies. This matches the laissez faire attitude of the Portuguese government that has been observed in recent years. The recent adoption of "sustainable tourism" as a buzz world by international and national bodies risks becoming a mere act of "usurpation of alternative tourism" in which, as Higgins-Desbiolles points out, these governing organs attempt to

"co-opt and divert opposition by adopting the language of social responsibility and sustainability [...] In particular, a critical analysis of the tourism industry's engagement with forces such as ecotourism, sustainability and PPT (pro-poor tourism) can be read as a dual strategy to prevent criticism and opposition while simultaneously securing notable benefits" (Higgins-Desbiolles 2008: 349).

Transforming tourism into an effective social force that can have positive social, economic and cultural effects on the region and on its visitors requires an abandonment of purely market-oriented approaches. We need a shift from the "tourism as industry" paradigm to a "tourism as social force" one (HigginsDesbiolles 2006: 1197). Promoting a sustainable tourism that is managed according to broad local interests and social-global objectives requires effective 
and tailored governance and a strong political will by the state (Bramwell 2011: 461; Bramwell and Lane 2011). Considering the relative weakness of Portugal's leaders, who face international pressure by the "Washington consensus" organizations, and the still-weak economic situation of Portugal, I am rather pessimistic as to whether the principles of sustainable tourism will be translated into concrete practices by the Portuguese government in the near future. As Higgins-Desbiolles pointed out, we should "pay attention to the wider context presented by a globalising capitalism, which promotes dynamics that are contradictory to achieving sustainable tourism" (Higgins-Desbiolles 2010: 118). The same author also claims that given the present economic condition and the almost uncontrolled spread of neoliberal economic policies and ideology, "sustainable tourism" might be doomed to remain an elusive concept.

Facing the inability or lack of interest of major ruling bodies (both at the national and the international levels) to address a change in the model of tourism, several authors have stressed the importance of a local definition of the policies of tourism development, criticizing one-size-fits-all economistic recipes and instead suggesting participatory and democratic processes for the definition of alternative tourism strategies (Ritchie 1993; Mowforth and Munt 1998; Stronza 2001; Higgins-Desbiolles 2008). These should acknowledge the capacity of local communities for action and resilience (Butler 2017), developing a participatory management model for regional tourism (Stronza 2001). Stronza suggests that alternative and eco-tourism, for example, can provide a holistic approach to tourism that considers the multiple interests of local and regional stakeholders: "Alternative tourism are forms of tourism that are consistent with natural, social, and community values, and which allow both hosts and guests to enjoy positive and worthwhile interaction and shared experiences" (Stronza 2001: 274). As early as 1993, J.R. Bent Ritchie developed a model for community-based processes for the definition of a longterm strategy of tourism development, claiming that:

"Increasingly, along with all important industry sectors, tourism is being critically assessed concerning its net contribution to the well-being of the community or region which it both serves and impacts on. [...] the residents of communities and regions affected by tourism are demanding to be involved in the decisions affecting their development" (Ritchie 1993: 379).

Salazar has rightly criticized the practical outcomes of community based tourism (Salazar 2012) and participation has been rightly denounced as a new legitimizing instrument of power elites (Miessen 2010). However, I suggest with Marcouiller that "a more cautious approach to tourism development, 
one that uses more integrative planning processes, has the opportunity to maximize the benefits of tourism while acting to ameliorate the negative impacts" (Marcouiller 1997: 337-338). Future research and action in tourism development in the Douro, I argue, will therefore have to facilitate and stimulate a participative and locally-based territorial and strategic plan that directs economic interests towards projects of sustainable and smart tourism, reduces negative ecological and sociological downturns, benefits local communities, and meets residents' expectations. In this whole process, it will be of central importance to grant local control and supervision of the expanding tourism sector in order to envisage, plan and put in practice a different model of tourism that acknowledges the importance of education for sustainable tourism in destination communities and with local investors (Moscardo and Benkendorff 2015; Moscardo and Murphy 2015; Moscardo 2015), and which enhances the resilience of local communities (Butler 2017).

\section{REFERENCES}

AMIT, Vered, and Noel DYCK, 2011, Young Men in Uncertain Times. Oxford and New York, Berghahn Books.

ARCE, Alberto, and Norman LONG, 2000, "Reconfiguring modernity and development from an anthropological perspective", in A. Arce and N. Long (eds.), Anthropology, Development and Modernities: Exploring Discourses, Counter-Tendencies and Violence, London and New York, Routledge, 1-31.

ATELJEVIC, Irena, Annette PRITCHARD, and Nigel MORGAN, 2007, The Critical Turn in Tourism Studies: Innovative Research Methodologies. Amsterdam, Elsevier.

BERNARDO, Edgar Alexandre da Cunha, 2015, Perceção dos Impactos do Turismo na Ilha da Boa Vista, Cabo Verde. Lisbon, ISCTE-IUL, doctoral thesis.

BERNARDO, Edgar Alexandre da Cunha (ed.), 2017, Para Um Enfoque Territorial do Turismo no Douro. Vila Real, UTAD, Working Paper Dourotur n. ${ }^{\circ}$ 3, available at $<$ http://dourotu r.utad.pt/wp-content/uploads/2018/04/TERRITO\%CC\%81RIO-DOUROTUR-2017_ FINALEdgar6.pdf $>$ (last access in December 2019).

BORDONARO, Lorenzo, 2009, “'Culture stops development!': Bijagó youth and the appropriation of developmentalist discourse in Guinea-Bissau)", African Studies Review, 52 (2): 69-92.

BORDONARO, Lorenzo, Yousra MAKANSE, and Gonçalo MOTA, 2017, "Relatório de missão, 26 junho - 10 agosto 2017". Vila Real, UTAD, available at $<$ http://dourotur.utad.pt/ wp-content/uploads/2017/09/Relat\%C3\%B3rio-de-Miss\%C3\%A3o-26-de-junho-a-10de-agosto.pdf $>$ (last access in December 2019). 
BOtelho, Rui Miguel Eira, 2012, Evolução Urbana da Cidade de Vila Real: Planeamento Municipal e a Sua Influência na Expansão Recente. Porto, Universidade do Porto, masters' dissertation.

BRAMWELL, Bill, 2011 , "Governance, the State and sustainable tourism: a political economy approach”, Journal of Sustainable Tourism, 19 (4-5): 459-477.

BRAMWELL, Bill, and Bernard LANE, 2011 , "Critical research on the governance of tourism and sustainability”, Journal of Sustainable Tourism, 19 (4-5): 41 1-421.

BRENNER, Neil, and Nik THEODORE, 2002, Spaces of Neoliberalism: Urban Restructuring in North America and Western Europe. Malden, MA, Blackwell.

BRITTON, Stephen G., 1982, "The political economy of tourism in the Third World", Annals of Tourism Research, 9 (3): 331-358.

BROHMAN, John, 1996, "New directions in tourism for Third World development", Annals of Tourism Research, 23 (1): 48-70.

BUTLER, Richard W., 1999, "Sustainable tourism: a state-of-the-art review", Tourism Geographies, 1 (1): 7-25.

BUTLER, Richard, 2017, “The tourist experience: can we maintain authenticity? Implications for tourism destination communities", paper presented at the XII Fórum Internacional do Turismo: "Turismo em 2017: Tendências e Oportunidades para os Destinos", 16 February 2017, Vila Nova de Gaia.

CABRAL, Maria Dolores, and Ricardo SOUSA, 2001, "Indicadores de localização, especialização e diversificação e análise shift-share: uma aplicação às NUT III da Região Norte no período 1986-1998”, Working Paper, Núcleo de Investigação em Políticas Económicas, Universidade do Minho.

CAMILLERI, M.A., 2016, "Responsible tourism that creates shared value among stakeholders”, Tourism Planning \& Development, 13 (2): 219-235.

CATON, Kellee, 2012, "Taking the moral turn in tourism studies", Annals of Tourism Research, 39 (4): 1906-1928.

CCDR-N - Comissão de Coordenação e Desenvolvimento Regional do Norte, 2008a, Plano de Desenvolvimento Turístico do Vale do Douro: PDTVD 2007-2013. Estrutura de Missão do Douro, Comissão de Coordenação e Desenvolvimento Regional do Norte, available at < http://www.ccdr-n.pt/sites/default/files/ficheiros_ccdrn/missaodouro/pdtvd_2007_2 013.pdf $>$ (last access in December 2019).

CCDR-N - Comissão de Coordenação e Desenvolvimento Regional do Norte, 2008b, Plano de Ação para o Desenvolvimento Turístico do Norte de Portugal: Pacto Regional para a Competitividade da Região Norte de Portugal. Comissão de Coordenação e Desenvolvimento Regional do Norte, available at < http://www.ccdr-n.pt/sites/default/files/planoaccaoturismo. pdf $>$ (last access in December 2019).

CCDR-N - Comissão de Coordenação e Desenvolvimento Regional do Norte, 2013, Diagnóstico Prospetivo da Região do Norte 2014-2020. Comissão de Coordenação e Desenvolvimento Regional do Norte, available at < http://www.qren.pt/np4/np4/?newsId=3608\&fileName=diagnostnorte2020_16072013.pdf $>$ (last access in December 2019).

CCDR-N - Comissão de Coordenação e Desenvolvimento Regional do Norte, 2014, Plano de Monitorização do Alto Douro Vinhateiro: Paisagem Cultural Evolutiva e Viva. Comissão de Coordenação e Desenvolvimento Regional do Norte, available at < http://www.ccdr-n.pt/ sites/default/files/ficheiros_ccdrn/missaodouro/plano_de_monitorizacao_19-01-2015. pdf $>$ (last access in December 2019). 
CLARKE, Jackie, 1997, "A framework of approaches to sustainable tourism”, Journal of Sustainable Tourism, 5 (3): 224-233.

CRISTÓVÃO, Artur (ed.), 2005, Avaliação Estratégica da Acção Integrada de Base Territorial do Douro, final report of the "AIBT-Douro" project, Vila Real.

CRISTÓVÃO, Artur, et al., 2003, “O espaço rural e os novos instrumentos de intervenção territorializada: o caso da AIBT-Douro", paper presented at the $V$ Colóquio Hispano-Português de Estudos Rurais: "Futuro dos Territórios Rurais Numa Europa Alargada", available at $<$ http://sper.pt/oldsite/VCHER/Pdfs/Artur_Cristovao\%20.pdf > (last access in December 2019).

CUI, Xiaoming, and Chris RYAN, 2011, "Perceptions of place, modernity and the impacts of tourism: differences among rural and urban residents of Ankang, China - a likelihood ratio analysis", Tourism Management, 32 (3): 604-615.

D'ERAMO, Marco, 2017, Il Selfie Del Mondo: Indagine sull'Età del Turismo. Milano, Feltrinelli.

EADINGTON, William R., and Valene L. SMITH, 1992, "Introduction: the emergence of alternative forms of tourism", in V.L. Smith and W. R. Eadington (eds.), Tourism Alternatives: Potentials and Problems in the Development of Tourism. Philadelphia, University of Pennsylvania Press, 1-12.

EISENSTADT, Shmuel N., 2001, "Multiple modernities", Daedalus, 129 (1): 1-31.

GAONKAR, Dilip Parameshwar, 2001, "On alternative modernities", in Dilip Parameshwar Gaonkar (ed.), Alternative Modernities, Durham and London, Duke University Press, $1-23$.

GOMES, D.A.A.M., and M.A.P. DINIS, 2006, "Qualidade de vida urbana: o papel das NUT III nos indicadores de desenvolvimento sustentável”, in J. F. G. Mendes et al. (eds.), PLURIS 2006: Anais do 2. Congresso Luso Brasileiro para o Planejamento Urbano, Regional, Integrado e Sustentável, Universidade do Minho, Universidade de São Paulo, Universidade Estadual Paulista, CD-ROM.

GOODWIN, Harold, 2007, "Advances in responsible tourism”, Leeds, International Centre for Responsible Tourism, ICRT Occasional Paper n. ${ }^{\circ} 8$, availble at $<$ https://www.academ ia.edu/2985953/Advances_in_Responsible_Tourism_Harold_Goodwin $>$ (last access in December 2019).

GOODWIN, Harold, 2016, Responsible Tourism. Oxford, Goodfellow Publishers.

GOODWIN, Harold, 2017, “The challenge of overtourism”, Responsible Tourism Partnership, Working Paper n. ${ }^{\circ}$ 4, available at < http://haroldgoodwin.info/pubs/RTP'WP4Overto urism01'2017.pdf > (last access in December 2019).

HALl, Tim, and Phil HUBBARD (eds.), 1998, The Entrepreneurial City: Geographies of Politics, Regime, and Representation. Chichester, Wiley.

HARVEY, David, 1989, "From managerialism to entrepreneurialism: the transformation in urban governance in late capitalism”, Geografiska Annaler: Series B, Human Geography, 71 (1), 3-17.

HIGGINS-DESBIOLLES, Freya, 2006, “More than an 'industry': the forgotten power of tourism as a social force", Tourism Management, 27 (6): 1192-1208.

HIGGINS-DESBIOLLES, Freya, 2008, “Justice tourism and alternative globalisation”, Journal of Sustainable Tourism, 16 (3): 345-364.

HIGGINS-DESBIOLLES, Freya, 2010, “The elusiveness of sustainability in tourism: the culture-ideology of consumerism and its implications", Tourism and Hospitality Research, 10 (2): 116-129. 
INE - Instituto Nacional de Estatística, 2002, Resultados Definitivos dos Censos 2001. Lisbon, INE.

INE - Instituto Nacional de Estatística, 2012, Resultados Definitivos dos Censos 2011. Lisbon, INE.

JAFARI, Jafari, 1990, "Research and scholarship: the basis of tourism education", Journal of Tourism Studies, 1 (1): 33-41.

JURDAO ARRONES, Francisco, 1992, "Los mitos del turismo", em Francisco Jurdao Arrones (ed.), Los Mitos del Turismo. Madrid, Endymion, 15-88.

KASTENHOLZ, Elisabeth, et al., 2014, Reinventar o Turismo Rural em Portugal: Cocriação de Experiências Turísticas Sustentáveis. Aveiro, UA Editora.

LESLIE, David (ed.), 2012, Responsible Tourism: Concepts, Theory and Practice. Wallingford, $\mathrm{CAB}$ International.

LICHTBLAU, Klaus, 1999, "Differentiations of modernity", Theory, Culture, and Society, 16: $1-30$.

LIU, Zhenhua, 2003, "Sustainable tourism development: a critique”, Journal of Sustainable Tourism, 11 (6): 459-475.

MARCOUILLER, D.W., 1997, “Toward integrative tourism planning in rural America”, Journal of Planning Literature, 11 (3): 337-357.

MATHIESON, Alister, and Geoffrey WALL, 1982, Tourism: Economic, Physical and Social Impacts. Harlow, Longman.

MeETHAN, Kevin, 2001, Tourism in Global Society: Place, Culture, Consumption. New York, Palgrave.

MIDDLETON, Victor T.C., and Rebecca HAWKINS, 1998, Sustainable Tourism: A Marketing Perspective. Oxford, Butterworth-Heinemann.

MIESSEN, Markus, 2010, The Nightmare of Participation. New York/Berlin, Sternberg Press.

MOSCARDO, Gianna, 2015, "The importance of education for sustainability in tourism", in G. Moscardo and P. Benkendorff (eds.), Education for Sustainability in Tourism: A Handbook of Processes, Resources and Strategies. Heidelberg, Springer International Publishing, $1-21$.

MOSCARDO, Gianna, and Laurie MURPHY, 2015, "Educating destination communities for sustainability in tourism”, in G. Moscardo and P. Benkendorff (eds.), Education for Sustainability in Tourism: A Handbook of Processes, Resources and Strategies. Heidelberg, Springer International Publishing, 135-154.

MOSCARDO, Gianna, and Pierre BENKENDORFF (eds.), 2015, Education for Sustainability in Tourism: A Handbook of Processes, Resources and Strategies. Heidelberg, Springer International Publishing.

MOWFORTH, Martin, and Ian MUNT, 1998, Tourism and Sustainability: New Tourism in the Third World. London, Routledge.

OLIVEIRA, Elsa, 2014, "Portugal: uma síntese estatística regional até ao nível de município", Temas Económicos, 22: 7-77.

PÉREZ, Xerardo Pereiro, and Cebaldo de León Smith INAWINAPI, 2007, Los Impactos del Turismo en Kuna Yala (Panamá): Turismo y Cultura entre los Kuna de Panamá. Madrid, Editorial Ramon Areces.

PICARD, David, 2011, Tourism, Magic and Modernity: Cultivating the Human Garden. New York and Oxford, Berghahn Books. 
PINA, Maria Helena Mesquita, 2007, O Alto Douro: Um Espaço Contrastante em Mutação. Lisbon, Imprensa Nacional - Casa da Moeda.

RIBEIRO, Manuela, 1998, “Turismo rural e desenvolvimento na Região do Douro", Douro: Estudos e Documentos, 3 (6): 25-49.

RIBEIRO, Manuela, 2000, "Procuras urbanas, ambiente(s) e desenvolvimento de regiões do interior", Douro: Estudos e Documentos, 10 (2): 31-43.

RIBEIRO, Manuela, and Carlos MARQUES, 2002, "Rural tourism and the development of less favoured areas: between rhetoric and practice", International Journal of Tourism Research, 4 (3): $211-220$.

RITCHIE, J.R. Brent, 1993, “Crafting a destination vision”, Tourism Management, 14 (5): 379-389.

ROFEL, Lisa, 1999, Other Modernities: Gendered Yearnings in China after Socialism. Berkeley, University of California Press.

SALAZAR, Noel, 2010, Envisioning Eden: Mobilizing Imaginaries in Tourism and Beyond. New York and Oxford, Berghahn.

SALAZAR, Noel, 2012, "Community-based cultural tourism: issues, threats and opportunities”, Sustainable Tourism, 20 (1): 9-22.

SHARPLEY, Richard, 2000, "Tourism and sustainable development: exploring the theoretical divide", Journal of Sustainable Tourism, 8 (1): 1-19.

SHARPLEY, Richard, 2015, “Tourism: a vehicle for development?", in R. Sharpley and D. J. Telfer (eds.), Tourism and Development: Concepts and Issues. Bristol, Channel View, 3-30.

SILVA, Luís, 2006, "Os impactos do turismo em espaço rural", Antropologia Portuguesa, 22 (23): 295-317.

SINGH, Tejvir, 2012, Critical Debates in Tourism. Bristol, Channel View Publications.

SMITH, Michael D., and Richard S. KRANNICH, 1998, "Tourism dependence and resident attitudes", Annals of Tourism Research, 25 (4): 783-802.

SOUSA, Carlos Alberto Fernandes de, 2013, Impacto no Turismo da Região Demarcada do Alto Douro Vinhateiro, após a Classificação de Património Mundial da Humanidade pela UNESCO. Bragança, Instituto Politécnico de Bragança, masters' dissertation.

SPENCELEY, Anna (ed.), 2008, Responsible Tourism. London, Earthscan.

STRONZA, Amanda, 2001, "Anthropology of tourism: forging new ground for ecotourism and other alternatives", Annual Review of Anthropology, 30: 261-283.

THOMAS, Philip, 2002, "The river, the road, and the rural-urban divide: a postcolonial moral geography from southeast Madagascar”, American Ethnologist, 29 (2): 366-391.

TPNP - Turismo do Porto e Norte de Portugal, 2015, Estratégia de Marketing Turístico do Porto e Norte de Portugal: Horizonte 2015-2020. Turismo do Porto e Norte de Portugal, available at < http://www.portoenorte.pt/fotos/gca/plano_estrategico_10327505915894b4d3a97 8b.pdf $>$ (last access in December 2019).

TPNP - Turismo do Porto e Norte de Portugal, 2017, Plano de Ação e Orçamento PNP 2017. Turismo do Porto e Norte de Portugal, available at < http://www.portoenorte.pt/fotos/g ca/0-pnp_planoacao2016_final_199041297459413aaa8293d.pdf $>$ (last access in December 2019).

TURISMO DE PORTUGAL, 2016, Estratégia Turismo 2027: Liderar o Turismo do Futuro. Lisbon, Turismo de Portugal, available at < http://estrategia.turismodeportugal.pt/sites/default/ files/Estrategia_Turismo_Portugal_ET27.pdf > (last access in December 2019). 
TURNER, Louis, and John ASH, 1975, The Golden Hordes: International Tourism and the Pleasure Periphery. London, Constable.

URRY, John, and Jonas LARSEN, 2011 , The Tourist Gaze 3.0. London, Sage.

WEAVER, David, 2011 , "Can sustainable tourism survive climate change?", Journal of Sustainable Tourism, 19 (1): 5-15.

WU, Chung-Tong, 1982, "Issues of tourism and socioeconomic development", Annals of Tourism Research, 9 (3): 317-330.

YOUNG, George, 1973, Tourism: Blessing or Blight? Harmondsworth, Penguin.

Receção da versão original / Original version

Receção da versão revista / Revised version

Aceitação / Accepted

Pré-publicação online / Pre-published online
$2018 / 03 / 14$

$2018 / 06 / 25$

$2018 / 11 / 16$

$2019 / 12 / 31$ 